\title{
Morphology, phytochemistry and pharmacological aspects of Carica papaya, an review
}

Ashish B. Wadekar 1, Minakshee G. Nimbalwar 1, Wrushali A. Panchale 1, Bhushan R. Gudalwar 2, Jagdish V. Manwar ${ }^{2,}{ }^{*}$ and Ravindra L. Bakal ${ }^{1}$

${ }^{1}$ IBSS's Dr. Rajendra Gode Institute of Pharmacy, Mardi Road, Amravati-444 602, MS, India

${ }^{2}$ IBSS's Dr. Rajendra Gode College of Pharmacy, Mardi Road, Amravati-444 602, MS, India

GSC Biological and Pharmaceutical Sciences, 2021, 14(03), 234-248

Publication history: Received on 04 February 2021; revised on 10 March 2021; accepted on 12 March 2021

Article DOI: https://doi.org/10.30574/gscbps.2021.14.3.0073

\begin{abstract}
Present review focuses on theMorphology, phytochemistry and pharmacological aspects of Carica papaya (Linn). The plant is well known to us since ancient time. The plants are traditionally used to treat several conditions such as stomach disorders, diarrhea, skin diseases, male contraceptives, and home remedies for colds. Phytochemically, the whole plant contains lycopene, carotenoids, alkaloids, monoterpenoids, flavonoids, mineral, vitamins enzyme papain. This nutritious fruits feed the body and immune system. Various medicinal properties attributed to the plant and parts thereof includes antibacterial, anticancer, insecticidal, wound healing etc.
\end{abstract}

Keywords: Carica Papaya, Phytochemistry, Phytoconstituents, Pharmacological Activities

\section{Introduction}

Since the ancient period, plants have a long history of natural remedy in traditional medicine. Ethno-botanical information on medicinal plants and their usage by indigenous cultures is useful in the conservation of traditional cultures, biodiversity, to promote health care and drug development. WHO focusing attention towards the developing countries to encourage them to use herbal medicine, which they have been traditionally, used for centuries [1-13].

Papaya (Carica papaya Linn.) is one of the most cultivated plants in tropical countries and the most popular and economically important species among the caricaceae family [14]. It is a species of the flowering plants that is native to India, Malaysia, Indonesia, Philippines and Sri Lanka including Oman. Several Asian countries have cultivated the papaya on commercial basis. In some tropical countries, papaya is also cultivated as garden plant. The plant is a medium and a thinly branched tree with a single stem.

The average height is about 5 to $10 \mathrm{~m}$. The leaves of the plant are spirally arranged up to the top stem. Normally, the leaves are big with oval shape with about 20-28 in. diameter. All parts of the plant contain white latex. The flowers are 5-parted pale white color petals and highly dimorphic. Both the male and female flowers are fused to the petals. The female flowers contain ovary and its five petals twisted loosely connected at the base. All parts of papaya have medicinal values and have been used traditionally for the treatment number of diseases globally.

Traditionally, it is used mainly to treat several conditions such as stomach disorders, diarrhea, skin diseases, male contraceptives, and home remedies for colds. Good numbers of studies have indicated that papaya possesses significant anticancer activities for colorectal, prostate, cervical and breast cancers. The extracts from the fruit, seeds, and leaves of the selected plant have also been shown to have significant cytotoxic activities against cancer cell lines including

*Corresponding author: Jagdish V. Manwar

IBSS's Dr. Rajendra Gode College of Pharmacy, Mardi Road, Amravati-444 602, MS, India.

Copyright (@ 2021 Author(s) retain the copyright of this article. This article is published under the terms of the Creative Commons Attribution Liscense 4.0. 
breast, liver and cancer of hematopoietic cell lines [15]. Carica papaya is cultivated for its fruits, it is favored by the people of the tropics, as breakfast, and as ingredients in jellies, preserves, or cooked in various ways. Papain, the proteolytic enzyme has a wealth of industrial uses. It is used for meat-tenderizers and chewing gums [16]. This known by various names across various regions (see Table 1 ).

Table 1 Popular names of plant in various countries

\begin{tabular}{|l|l|}
\hline Region/ Country & Name \\
\hline Southern Asia and East Indies & Kapaya, kepaya, lapaya and tapaya \\
\hline Australia and West Indies & Papaw or paw paw \\
\hline Brazil & Mamao (big breast) or tree melon \\
\hline Spain & $\begin{array}{l}\text { Melon zapote, lechosa, papaya (the fruit), papyo @ } \\
\text { papyero(the plant), frutabomba, mammon and mamona }\end{array}$ \\
\hline France & Papaya (the fruit), papayer(the plant) or "figuier des Iles" \\
\hline Vietnam & Du du \\
\hline New Zealand & Papaw \\
\hline Venezuela & Lechoso (milky) \\
\hline Cuba & Fruitabomba (fruit bomb) \\
\hline
\end{tabular}

\section{Taxonomy, morphology and botanical description}

\subsection{Taxonomy}

Plant taxonomy is the science that finds, identifies, describes, classifies, and names plants. Taxonomy of Carica papaya is given in Table 1.Plant taxonomy is closely allied to plant systematic, and there is no sharp boundary between the two. In practice, "Plant systematics" involves relationships between plants and their evolution, especially at the higher levels, whereas "plant taxonomy" deals with the actual handling of plant specimens.

\subsection{Morphology}

The papaya is a polygamous species. The plants may be classified into three primary sex types such as (i) Male (staminate), (ii) Hermaphroditic (bisexual), and (iii) Female (pistillate). In addition, some plants can produce, at the same time, more than one kind of flower. Also, some produce flowers that are not of these basic forms, but exhibit different degrees of maleness and femaleness. This tendency to change in sexual expression seems to be triggered by climatic factors, such as drought and variable temperatures [17].

The tendency to produce male flowers seems to increase at high temperatures. Since male trees are unfruitful and fruit from bisexual plants is preferred in some markets, it is very important to select seed which will produce fruitful trees of the desired type. One can predict fairly accurately the progeny by knowing the source of pollen and the kind of flower. The fruit came from Pollination studies have shown that (i) Pistillate flowers pollinated by staminate flowers give equal numbers of male and female progeny, (ii) Pistillate flowers pollinated by pollen from bisexual flowers give an equal number of female and bisexual progeny, (iii) Bisexual flowers either self or crossed-pollinated with other bisexuals give a ratio of one female to two bisexual. Bisexual flowers pollinated by staminate ones produce equal numbers of female, male and bisexual progeny. It is evident that the second and third combinations will produce the maximum number of fruit-bearing plants [18].

\subsubsection{Leaves}

The leaves are spirally arranged in a terminal cluster, simple, on petioles 30-70 cm long. The margins of the lobes are very variable, and range from entire to undulate to deeply lobed. The leaves are rounded in outline, 60-90 $\mathrm{cm}$ in diameter, alternately arranged, bundled at the apex between stem and branches, long petioles; widely evident, 25-75 $\mathrm{cm}$ diameter, smooth, moderately palm shape with thick middle irradiant veins, the base is deeply string shape with over-imposed lobes; from 7-11 large lobed, each with a wide base or slightly constrained and sharp-pointed, and sharp apex. The bundle of leaves is dark green to yellow-green, bright, visibly marked by the off-white nerves embedded and 
reticulated veins; the underneath surface is pale green-yellow and opaque with visibly prominent vascular structures; the petioles are round and yellow-green, with sporadic purple or violet stains, fistulous form, fragile, 25-100 cm length and $0.5-1.5 \mathrm{~cm}$ thick. The lifespan of each leaf is 4 to 6 months.

\subsubsection{Flowers}

Flowers are the reproductive structure found in flowering plants. The biological function of a flower is to facilitate reproduction. Six types of flowers are known in papaya plant.

\section{Typical female flower}

It is a rather large flower of conical shape when closed, when open, its five petals spread from the base. The ovary is large with circular and smooth or slightly undulated. Fruits produced by this flower are spherical or ovoid in shape.

Similar to the above when closed

but this type has five short anthers, which correspond in their orientation with the five petals that also spread from the base. The ovary has five deep longitudinal grooves that remain until maturity. Fruit develops a form from globular to egg-shaped.

\section{Hermaphrodite intermediate flower}

The organization is undefined; petals may be fused up to two thirds of their length or free from the base. The number of anthers ranges from two to ten; the carpels range from five to ten, with different degrees of fusion. This type of flower produces irregularly-shaped fruit known as carpelodic (cat face), with little commercial value. These flowers appear more frequently when ambient temperatures are $24.5^{\circ} \mathrm{C}$ during the day and $15.5^{\circ} \mathrm{C}$ at night.

\section{Hermaphrodite elongated flower}

Petals of this type of flower are fused from one fourth to three fourths of their total length; ten anthers are observed, five long and five short. The ovary is long and when it contains five or more carpels, the form of the fruit varies from cylindrical to pear-shape. From the different types of hermaphrodite flowers, this is the most commercially important.

\section{Hermaphrodite sterile flower}

It is a flower that resembles the former, but does not develop an ovary and hence it is sterile, warm temperatures or water stress. Due to the fact that it produces pollen only, it may be considered a functional male flower

\section{Typical male flower}

This type of flower has a long and thin corolla contain anthers in two series of five; one series longer than the other. They have a rudimentary pistil no stigma and are non-functional. In nature, these plants are dioecious: male and female flowers are found on separate plants. Male flowers are morphologically distinct from female flowers. Male inflorescences are borne in many-flowered panicles of cymes on horizontal or pendent stalks to $1 \mathrm{~m}$ long. The flowers are yellowish, 2-4 cm long. The petals are fused into a long tube, have 10 fertile stamens, and a rudimentary, nonfunctional ovary. Female inflorescences are much shorter -only 3-4 cm long- and have fewer flowers. Female flowers are larger, usually white or cream in color, with five free petals. There are no stamens, but a large ovary with 5 fanshaped stigmas.

In cultivation, there are many intermediate forms, including bisexual flowers. At least 15 different flower forms have been named (e.g.Pentandria-5 stamens and a functional ovary) and, because they are correlated with different fruit characteristics, some forms, have been selected by breeders. Environmental factors may also influence sexual expression, and the sexuality of a plant may change seasonally or over the course of its lifetime. Thus the sexuality of any one plant in cultivation depends on a complex mix of genetic, developmental, and environmental factors.

Female flowers have a calyx formed by a crown or five-pointed star easy to differentiate. On top of the calyx, the ovary is located by five yellowish sepals (when young, they show a purple coloration. There are five round-shaped yellow stigmas. Fruits from this flower are usually large and balloon-like. Hermaphroditic flowers have both sexes and the tree bearing these has three different types of flowers. One is called pentandria, resembling a female flower, but when petals are taken apart 5 anthers are seen and the ovary is lobed. Fruit are balloon-shaped and lobed. A second type of flower is called elongata and bears 10 anthers, arranged in two sets, the flower is elongated and cylindrical as the ovary and 
produce elongated fruits. The last type is intermedia or irregular, which is not a well-constituted flower and produces malformed fruit.

Male flowers grow along peduncles measuring over half a meter length and at the end there are bundles formed by 1520 small flowers. These flowers are constituted by a long tube formed by fused petals, inside which there are 10 anthers, arranged in two sets of five. The flower has a small rudimentary pistil and has no stigmas. No fruit are usually produced, or if formed these are elongated and of low quality.

\subsubsection{Fruits}

An ovoid-oblong berry pyriform or almost cylindrical, large, fleshy, juicy, grooved along the upper longer side, green yellow to yellow or yellow-orange color when ripen, single cell of orange or reddish internal color with many parietal seeds and a length of $10-25 \mathrm{~cm}$ or longer and 7-15 cm or more of diameter. Generally, the fruit is melon-like, oval to nearly round, somewhat pyriform, or elongated club-shaped, 15-50 cm long and 10-20 cm thick; weighing up to $9 \mathrm{~kg}$. Semi-wild (naturalized) plants bear miniature fruits $2.5-15 \mathrm{~cm}$ long. The skin is waxy and thin but fairly tough. When the fruit is green and hard it is rich in white latex. As it ripens, it becomes light or deep-yellow externally and the thick wall of succulent flesh becomes aromatic, yellow, orange or various shades of salmon or red. It is then juicy, sweetish and somewhat like a cantaloupe in flavor; in some types quite musky. Attached lightly to the wall by soft, white, fibrous tissue, are usually numerous small, black, ovoid, corrugated, peppery seeds about 3/16 in (5 mm) long, each coated with a transparent, gelatinous [17,18,19] (Table 2).

Table 2 Nutritional value of fruit

\begin{tabular}{|c|c|c|}
\hline Constituent & Ripe Papaya & Green Papaya \\
\hline Water & $89.1 \mathrm{gm}$ & $92.6 \mathrm{gm}$ \\
\hline Proteins & $8.26 \mathrm{gm}$ & $10.8 \mathrm{gm}$ \\
\hline Total lipid & $0.93 \mathrm{gm}$ & $1.35 \mathrm{gm}$ \\
\hline Ash & $4.59 \mathrm{gm}$ & $6.76 \mathrm{gm}$ \\
\hline Carbohydrates & $86.2 \mathrm{gm}$ & $81.1 \mathrm{gm}$ \\
\hline Total DF & $11.9 \mathrm{gm}$ & $27.0 \mathrm{gm}$ \\
\hline \multicolumn{3}{|c|}{ Mineral Macronutrients } \\
\hline Sodium & $128.4 \mathrm{mg}$ & $283.8 \mathrm{mg}$ \\
\hline Potassium & $1238 \mathrm{mg}$ & $2743 \mathrm{mg}$ \\
\hline Magnesium & $229.4 \mathrm{mg}$ & $635.1 \mathrm{mg}$ \\
\hline Calcium & $146.8 \mathrm{mg}$ & $635.1 \mathrm{mg}$ \\
\hline \multicolumn{3}{|l|}{ Micronutrients } \\
\hline Iron & $12.84 \mathrm{mg}$ & $8.11 \mathrm{mg}$ \\
\hline Copper & $0.18 \mathrm{mg}$ & $0.14 \mathrm{mg}$ \\
\hline Zinc & $0.92 \mathrm{mg}$ & 0 \\
\hline \multicolumn{3}{|l|}{ Vitamins } \\
\hline Vitamin & $568.8 \mathrm{mg}$ & $391.9 \mathrm{mg}$ \\
\hline Thiamine & $0.28 \mathrm{mg}$ & $0.54 \mathrm{mg}$ \\
\hline Riboflavin & $0.28 \mathrm{mg}$ & $26 \mathrm{mg}$ \\
\hline Niacin & $2.80 \mathrm{mg}$ & $4.05 \mathrm{mg}$ \\
\hline Carotene & $7807 \mu \mathrm{g}$ & 0 \\
\hline
\end{tabular}




\subsubsection{Seeds}

The seeds account for about $16 \%$ of the fresh fruit weight and each seed is made up of sarcotesta and endosperm. papaya seed extracts had been shown to have several medicinal as well as nutritional properties Several species of Caricaceae have been used as medication against a variety of diseases It had been argued by scientists that all parts of a pawpaw plant, including the seeds, roots, rinds, and fruits have positive effects on general health preventing diseases. See Fig. 1 for various parts of plant.

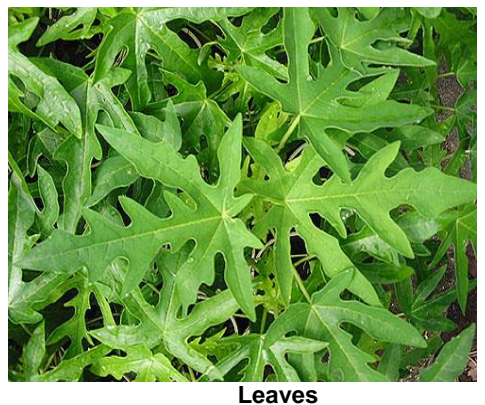

Leaves

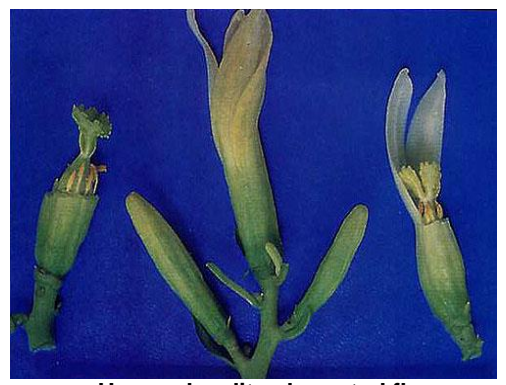

Hermaphrodite elongated flower

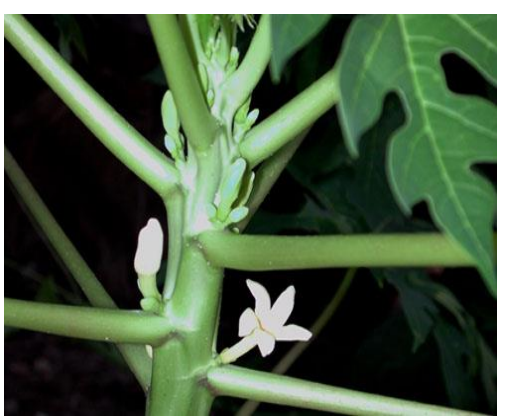

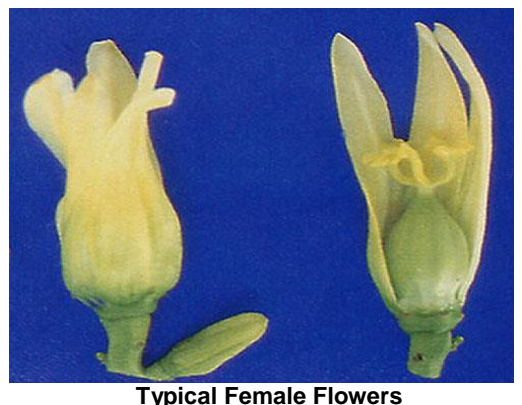

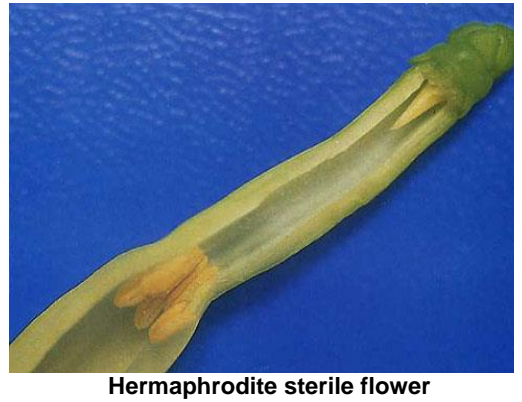

Hermaphrodite sterile flowe

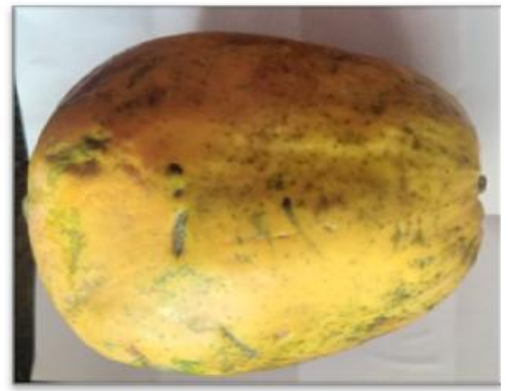

Figure 1 Various parts of Carica papaya plant

\subsection{Botanical description}

Carica branched due to injury, containing white latex in all parts. Stem cylindrical, 10-30 cm in diameter, hollow with papaya is an evergreen, tree-like herb, 2-10 m tall, usually unbranched, although sometimes prominent leaf scars and spongy-fibrous tissue. Has an extensive rooting system. Leaves spirally arranged, clustered near apex of trunk; petiole up to $1 \mathrm{~m}$ long, hollow, greenish or purplish-green; lamina orbicular, 25-75 cm in diameter, palmate, deeply 7-lobed, glabrous, prominently veined; lobes deeply and broadly toothed. Flowers tiny, yellow, funnel-shaped, solitary or clustered in the leaf axils, of 3 types; female flowers 3-5 cm long, large functional pistil, no stamens, ovoid-shaped ovary; male flowers on long hanging panicles, with 10 stamens in 2 rows, gynoecium absent except for a pistillode; hermaphrodite flowers larger than males, 5-carpellate ovary; occurrence depends on the season or age of the tree.

Fruits large, cylindrical, with fleshy orange pulp, hollow berry, thin yellowish skin when ripe, varied. Fruits formed from female flowers are oblong, spherical, and pear-shaped; from hermaphrodite flowers, long, obovoid or pyriform. Seeds numerous, small, black, round, covered with gelatinous aril. Small latex vessels extend throughout the tree and are particularly abundant in fruit that has reached full size but has not yet begun to ripen. The generic name is from the Latin 'carica', meaning 'edible fig', on account of the similarity of the leaves.

Carica papaya comes into fruiting within 5 months and lives for 4-5 years. Usually male and female flowers are on different trees, but some flowers are bisexual. Pollinating agents include various insects such as larger bees 
(Xylocarp,Trigona), honeybees, long-tongued sphinx moths (Sphingidae), humming-bird moths (Macroglossa) and wind. With open (uncontrolled) pollination, a cultivar may lose its identity in a few generations.

C. papaya grows satisfactorily in a wide range of areas from the equatorial tropics to temperate latitudes. However, it must be grown in warm, sunny sites sheltered from wind; preferably below $1500 \mathrm{~m}$. Strong winds are detrimental, particularly on soils that cannot make up for large transpiration loss. C. papaya is not frost hardy; exposure to frost or cold wind usually results in leaf damage and subsequent death of the tree. Roots are very sensitive to water logging, and even short periods of flooding can kill the plant $[20,21]$ (see Table 3).

Table 3 Botanical Classification of plant

\begin{tabular}{|l|l|}
\hline Domain & Flowering plant \\
\hline Kingdom & Plantae \\
\hline Sub Kingdom & Tracheobionta \\
\hline Class & Magnoliopsida \\
\hline Subclass & Dilleniidae \\
\hline Super division & Spermatophyta \\
\hline Phyllum & Steptophyta \\
\hline Order & Brassicales \\
\hline Family & Caricaceae \\
\hline Genus & Carica \\
\hline Botanical name & Carica papaya Linn. \\
\hline
\end{tabular}

\section{Phytoconstituents of plant}

Medicinal activities of the plants are attributed to active chemical compounds (ACC) present in the plant. These compounds may be volatile or non-volatile [22-35]. There are various analytical techniques by which active chemical compounds are determined. These methods can also be used for analysis of ACC in pharmaceutical formulations including ayurvedic products [36-41].

Papaya leaves contain tannin, saponin, alkaloids, flavonoids, and glycosides; while shoots contain various minerals like $\mathrm{Ca}, \mathrm{Fe}, \mathrm{Mg}, \mathrm{K}, \mathrm{Zn}, \mathrm{Mn}$ etc. Enzymes are present in the unripe fruit such as papain and chymopapain. Fruit also contains carotenoids $\beta$ carotene and crytoxanthin. The chemical composition of the root showed the presence of benzyl isothiocyanate, glucosinolatescarposide. Papaya oil is found in seeds and also contains flavonoids, kaemferol, myricetin, and fruit contains Linalool, 4-terpinol, monoterpenoids. Papaya leaves contain tannin, saponin, alkaloid, flavonoid, and glycoside; while shoots contain various minerals like $\mathrm{Ca}, \mathrm{Fe}, \mathrm{Mg}, \mathrm{K}, \mathrm{Zn}, \mathrm{Mn}$ etc. Enzymes are present in the unripe fruit such as papain and chymopapain.

Fruit also contains carotenoids $\beta$ carotene and crytoxanthin. The chemical composition of the root showed the presence of benzyl isothiocyanate, glucosinolatescarposide. Papaya oil is found in seeds and also contains flavonoids, kaemferol, myricetin, and fruit contains Linalool, 4-terpinol, monoterpenoids.

Enzymes were found in latex as well as in other parts of plants for example, papain, chymopapain, caricain, and protease omegan Latex of $C$. papaya was also reported to have enzymes like cysteine endopeptidases, chitinase, and glutaminyl cyclase Seven flavonoids were obtained from the papaya leaves, named as quercetin, kaempferol, kaempferol 3rutinoside, quercetin3-(2G-rham nosylrutinoside), quercetin 3-rutinoside, kaempferol 3-(2G-rhamnosylrutinoside), myricetin 3-rhamnoside.Fruit contains phytochemicals flavonoids-kaempferol, myricetin, quercetin and carotenoids lycopene, zeaxanthin, cryptoxanthin, $\beta$-carotene and violaxanthin.

Leaves the presence of the various phenolic compound in the leaves for example kaempferol, protocatechuic acid, quercetin, 5,7-dimethoxy coumarin, caffeic acid, p-coumaric acid, and chlorogenic acid in plant leaves. Another study by reported that $n$-hexane extract and methanolic extract of leaves showed the presence of different components such as 
anthraquinone, glycoside, tannin, saponin, flavonoid, steroid and resin. The major isolated compounds from leaves are protocatechuic acid, chlorogenic acid, caffeic acid, quercetin, kaempferol, quercetin 3-0- $\alpha$-1C4-rhamnopyranoside, quercetin-3-0-glucopyranuroside, quercetin-3-0-rutinoside, p-coumaric acid [42, 43, 44]. The chemical structures of phytoconstituents of plant are shown in Fig. 2 and phytoconstituents are shown in Table 4.

Table 4 Phytoconstituents of plant (8)

\begin{tabular}{|l|l|}
\hline Part & Phytoconstituents \\
\hline Fruits & $\begin{array}{l}\text { Protein, fat, carbohydrates, minerals, vitamins, volatile compound, alkaloids, } \\
\text { Glycosides. }\end{array}$ \\
\hline Juice & $\begin{array}{l}\text { N-butyric, n-hexanoic and n-octanoic acid, lipid, myristic, palmitic, stearic } \\
\text { linoleic, linolenic acid and oleic acid }\end{array}$ \\
\hline Seed & $\begin{array}{l}\text { Fatty acid, crude protein, crude fibres, papaiya oil, carpaine, benzyl } \\
\text { isothiocyanate, benzylthiourea, } \beta \text {-sitosterol, caricin and enzyme myrosin. }\end{array}$ \\
\hline Root & Caproside and enzyme myrosine \\
\hline Leaves & $\begin{array}{l}\text { Alkaloids carpain, pseudocarpain and dehydrocarpain 1,2, choline, caproside, } \\
\text { vitamin C and E. }\end{array}$ \\
\hline Bark & $\beta$-sitosterol, glucose, fructose, galactose and xylitol. \\
\hline Latex & $\begin{array}{l}\text { Proteolytic enzyme papain, chemopapain, glutamine cyclotransferase, } \\
\text { Chymopapain A,B,C, peptidase A and B, lysosome. }\end{array}$ \\
\hline
\end{tabular}

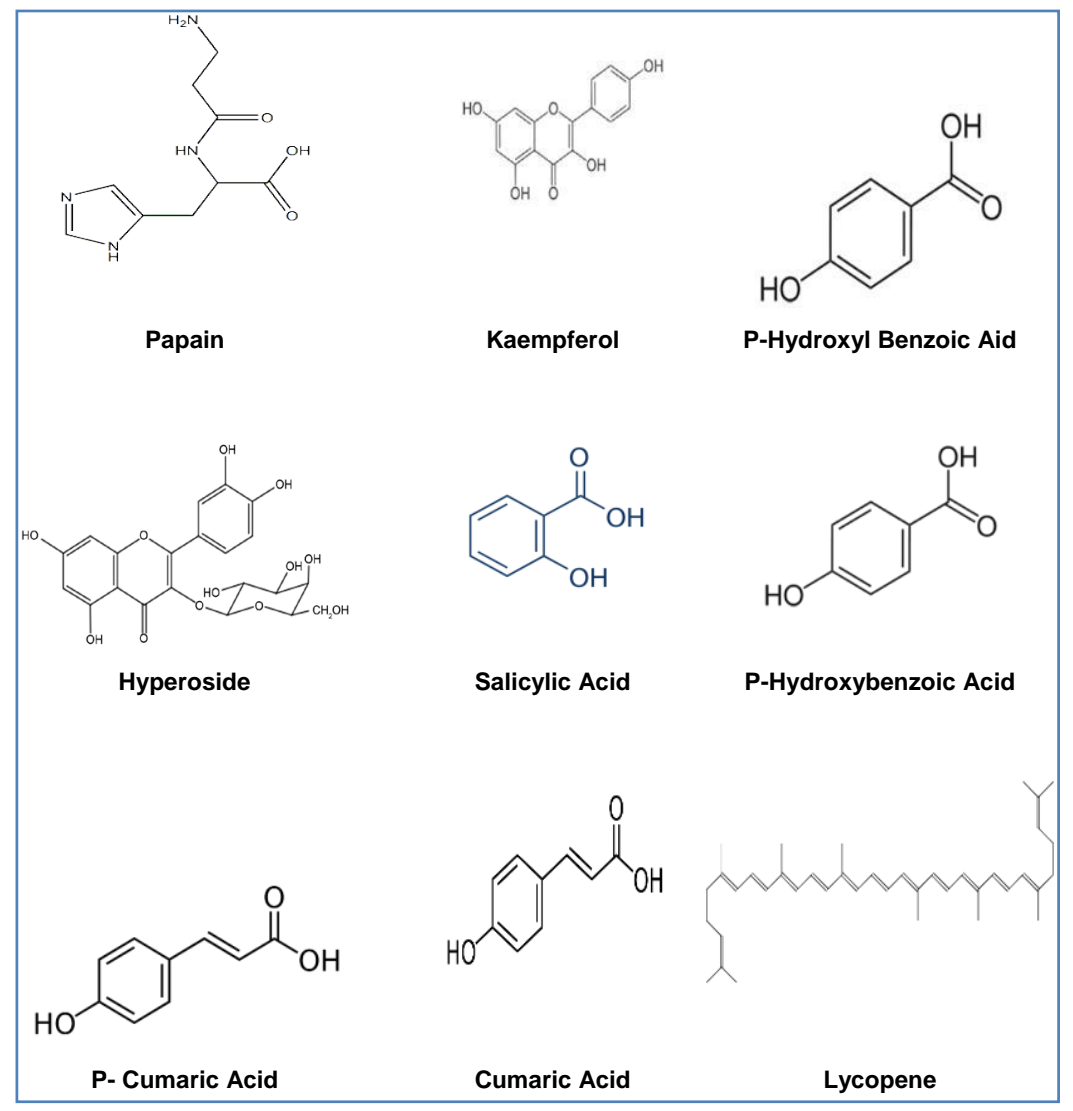

Figure 2Phytoconstituents of the plant 


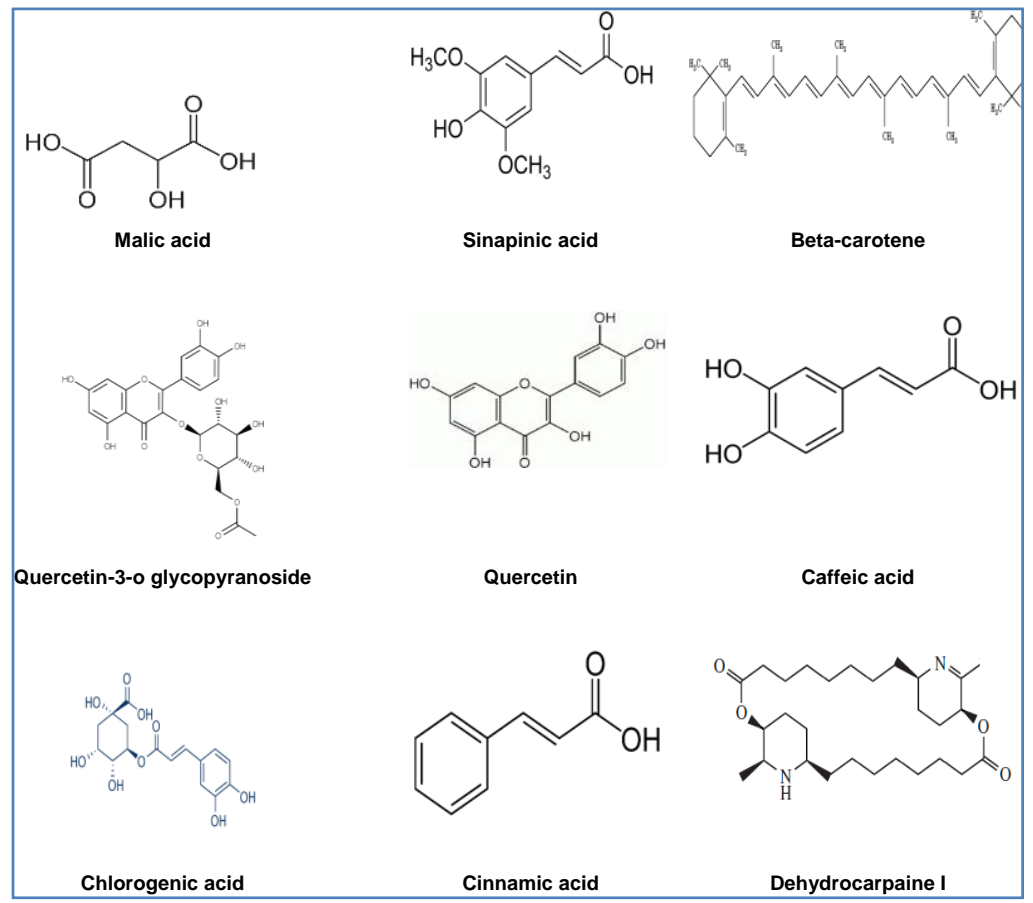

Figure 2 Continue...

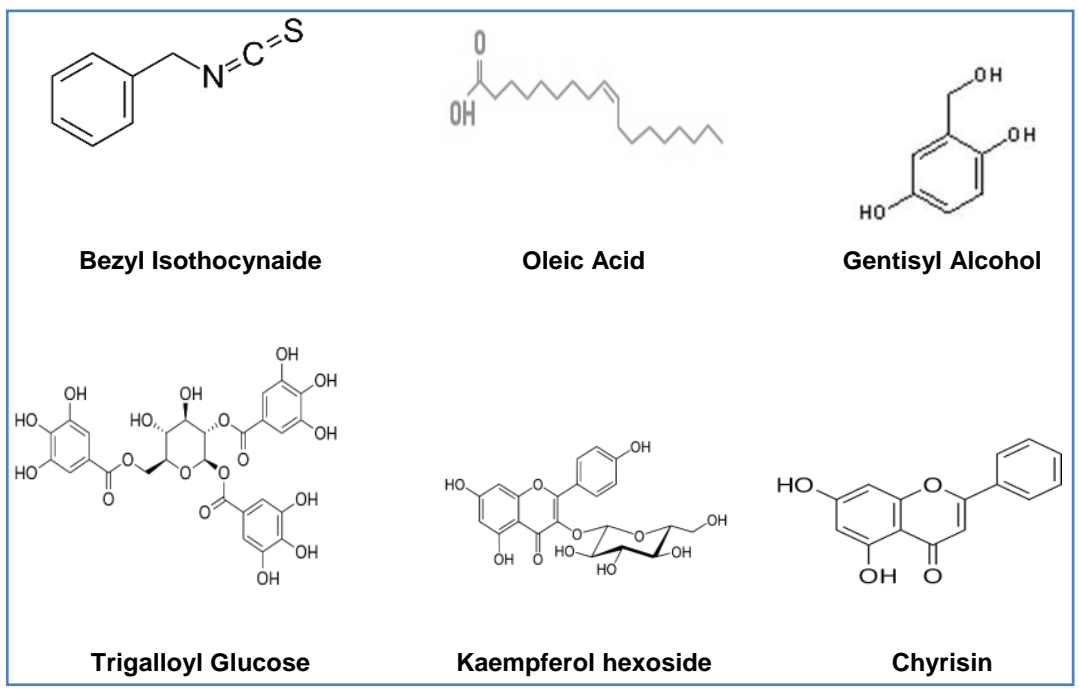

Figure 2 Continue...

\section{Pharmacological activities}

C. papaya is tremendously efficient in different types of ailment cure due to availability of wide varieties of phytoconstituents in almost all parts of plant. Antioxidant activity Free radical causes many chronic health problems. Antioxidants can help us by preventing the formation of free radicals. Research is going on to find new sources of antioxidants of natural origin which are safe and economically viable. According to a study hexane fraction of $C$. papaya male flower shows a good antioxidant activity (IC50 $=100.81 \pm 1.180$ ). Low IC50 value reflects a high antioxidant activity. The antioxidant capacity of fruit extract in the ripening stage was determined by different methods (Ferric reducing antioxidant power, 2,2-diphenyl-1-picrylhydrazyl (DPPH) and 2,2-azinobis-3-ethylbenzothiazoline-6-sul fonic acid) and result showed that the antioxidant activity papaya fruit increased in the ripening stage. Ethyl acetate extract of unripe fruit containing $\beta$-sitosterol and quercetin are responsible for the antioxidant properties. Silver nanoparticles (Ag-NPs) synthesized from C. papaya peel extract (CPPE), and was tested for their antioxidant activity. 
The result revealed that 56\% average inhibition for synthesized Ag-NPs and 38\% for CPPE at different concentrations and the activity is concentrations dependent on Ag-NPs. One recent research investigation reported that the antioxidant activity of methanolic extract of seeds was determined by DPPH free radical scavenging activity. In another study, papaya seed extracts were used to examine the antioxidant activity and results revealed that the highest DPPH free radical scavenging ability was found in hexane extract and the least activity in the aqueous extract study.

The antioxidant activity of papaya leaves with different varieties, maturity, and solvent. The solvents used for extraction were water, methanol, and ethanol 70\%. Results showed that mature leaves extracted with water exhibited the highest antioxidant activity higher than others. The enzyme PaMsrB1 (Plant methionine sulfoxidereductaseB1) from papaya was examined with Escherichia coli which contain MBP (Maltose binding protein) at its N terminal protease activity help in the digestion of MBP-tag and leads to the isolation of recombinant PaMsrB1. The purified recombinant protein PaMsrB1 showed the reductase activity against methionine sulfoxide (MetSO), DabsylMetSO in the presence of dithiothreitol. Various proteins that interact with PaMsrB1 were obtained and identified by affinity chromatography and LC-MS/MS. These results provide a platform to understand the defense mechanism of PaMsrB1 against antioxidative stress $[45,46]$.

The seed extract of $C$. papaya (petroleum-ether, benzene, ethyl acetate, chloroform: methanol (1:1 v/v) and crude extract can be useful for their larvicidal, pupicidal, adulticidal, repellent effects and smoke toxicity against Culex quinquefasciatus, malaria and Anopheles stephensi, respectively. The mortality rate of A. stephensi and C. quinquefasciatus at $0.5 \%$ concentration is more effective. It was found that the repellant effect against both female mosquitoes with protection percentages 78 and 92 respectively. Protection time against biting was $4 \mathrm{~h}$ for $\mathrm{C}$. quinquefasciatus and $5 \mathrm{~h}$ for A. stephensi. One research study showed toxic smoke test, 186 mosquitoes of An. stephensi and 190 mosquitoes of $C$. quinquefasciatus, out of 200 mosquitoes, died after $5 \mathrm{~h}$ of smoke. IR study provides information about the nature of the active component, polyhydroxyaliphatic amide.

One research study showed that peel and seed aqueous extract of papaya has a larvicidal activity for Aedes aegypti. It was also found that seed extract has higher larvicidal activity in comparison to peel extract. Perhaps, due to the presence of phytochemicals in extract such as flavonoids, tannins, and alkaloids. Another study showed that leaf, bark, root, and seeds possess insect repellent activity against Aedes aegypti. It was also found that crude ethanol extract was much effective in controlling the vector as compared to aqueous extract. Also, it was found that $C$. papaya leaf extract has the potential to develop as a source of natural insecticide against chikungunya, filaria and malaria vector mosquito.

Leaf extract of papaya in ethanol has the potential to act as natural insecticides to control the population of German cockroaches which are known to resistant against synthetic insecticides. Another research study revealed the toxic effect of leaf extract against Mustard aphid which is an important insect pest of various mustard species. Papain (enzyme) found in papaya has also been reported for its insecticidal activity $[47,48,49]$.

\subsection{Antibacterial activity}

Research investigation was carried out to check the antimicrobial activity of fresh and dried leaves extracts (acetone, aqueous, and ethanol) of papaya by disc diffusion method. Results exhibited that aqueous extracts were less effective as compared to organic extracts. It was also found that a fresh sample was more efficient against Gram-negative bacteria and the dry sample showed great efficiency against both Gram-positive and Gram-negative bacteria. Research investigation reported that ethyl acetate, chloroform, hexane, methanol, acetone, hot water, ethanol and petroleum ether leaf extracts of papaya extract exhibited antibacterial activity. antimicrobial activity of that methanolic and aqueous root extract papaya against seven were bacteria and four were fungi.

Papaya leaf extract showed antimicrobial activity against Pseudomonas aeruginosa. The leaf extract showed superior effects against all Gram-positive bacteria as compared to Gram-negative bacteria also reported the antibacterial activity of papaya leaf aqueous and methanolic extracts against Escherichia coli, Staphylococcus aureus, and Candida albicans. The antibacterial activity of the methanolic extract was significant compared to aqueous extract. Another report showed that methanolic seed extract was examined for the antibacterial activity by using Agar well diffusion method [50, 51, 52] (see Table 5). 
Table 5 Antimicrobial activities of Carica papaya

\begin{tabular}{|c|c|c|}
\hline Parts & Type of extract & Activity against \\
\hline Seeds & Methanol & E. coli, K. pneumonia, P. vulgaris \\
\hline $\begin{array}{l}\text { Seeds } \quad \& \\
\text { Leaves }\end{array}$ & $\begin{array}{l}\text { n-hexane, ethanol, ethyl acetate, } \\
\text { diethyl ether }\end{array}$ & $\begin{array}{l}\text { E. coli, } \text { S. aureus, Bacillus subtilis and } \\
\text { C. albicans }\end{array}$ \\
\hline Leaves & $\begin{array}{l}\text { Methanol and } \\
\text { aqueous }\end{array}$ & E. coli, S. aureus and C. albicans \\
\hline Peels & Aqueous & $\begin{array}{l}\text { E. coli, S. aureus, B. subtilis, } B . \\
\text { pumilus, K. pneumonia, Aspergillus niger, Candida Tropicalis } S . \\
\text { aureus }\end{array}$ \\
\hline Latex & Aqueous & $\begin{array}{l}\text { S. aureus, } P . \text { aeruginosa, } K . \text { aerogenes and Pseudomonas } \\
\text { desmolyticum, E. coli, } P . \text { fluorescens, B. subtilis, Salmonella typhi }\end{array}$ \\
\hline
\end{tabular}

\subsection{Anti-diarrheal responses}

Chloroform extract $(25 \mathrm{mg} / \mathrm{mL}$ ) of raw $C$. papaya and acetone extract $(25-0.39 \mathrm{mg} / \mathrm{mL}$ ) of ripe $C$. papaya had essential antidiarrheal activity against the gut pathogens. The antidiarrheal activity of ripe $C$. papaya extract was extensively seen against Plesiomonas shigelloides with ranges from $50 \mathrm{mg} / \mathrm{mL} 0.39 \mathrm{mg} / \mathrm{mL}$. DAS-77 (herbal mixture prepared dried root of $C$. papaya with young bark of Mangifera indica) effective in the treatment of diarrhoea. DAS-77 was tested on mice and the result showed that DAS-77 possesses antidiarrhoeal activity. In another study antidiarrheal activity of leaf aqueous extract of $C$. papaya was tested in rats' model and found that extract has good antidiarrheal activity and the extract was observed to be safe at $200 \mathrm{mg} / \mathrm{kg}$ in the case of rats model $[53,54,55]$.

\subsection{Wound-healing activity}

Various skin disorders as well as wounds can be cured by papaya. The ethanolic papaya seed extract was tested in Sprague-Dawley rats, for its wound-healing activity. Results showed that the seed extract assists wound healing in rats. C. papaya loaded PVA/Gelatin nano fibrous was prepared from leaves of $C$. papaya by electrospinning process. The fabricated nano fibers were hydrophilic and showed wound healing activity. It also exhibited strong antibacterial activity against both $S$. aureus (Gram-positive) and E. coli (Gram-negative). In a research investigation, the effect of aqueous extract of the root of C. papaya on wound healing in albino rats was checked and root extract showed wound healing activity. It was concluded that the extract-treated wound shows remarkable wound healing activity like standard FSC (Framycetinsulpha cream) [56, 57].

In comparison with control (80.38\%), tested animals reveal $89.40 \%$ reduction in wound part after treated by latex of $C$. papaya. In one research study, $C$. papaya stem was analyzed for its wound healing property in albino rats. Ten albino rats were used as experimental animals in two groups. The first group of five animals was treated with an antiseptic named Betadine, whereas other groups of five animals were treated with ointment obtained from C. papaya. Initial and mean size of the wound every two days interval showed no major effect. The final wound size in millimeters after fifteen days showed a major effect. This result suggested the wound healing activity of $C$. papaya in albino rats [58,59].

\subsection{Anticancer activity}

In vitro investigation of $C$. papaya suggested that it has anti-cancer properties. The plant contains an enzyme, namely papain which is a constituent of papaya and very helpful in cancer treatment. Fibrin breaks down by papain which coats the tumor cells into amino acid. The pigment lycopene is found inside the papain which is highly reactive towards free radical and oxygen. Papaya also contains isothiocyanate which protects the breast, prostate, pancreas, lung, leukemia, and colon cancer.

In a research study, it was revealed that the leaf extract of $C$. papaya can prevent the progression of cancerous cells. Various markers such as CA15-3 and LDH are the important biochemical parameter for the detection of cancerous cells; and it was found that the leaf extract in a dose of $200 \mathrm{mg} / \mathrm{kg}$ body weight has a significant effect to decrease both markers in the treatment of cancer. 
Petroleum ether, ethyl acetate, chloroform, and methanol (80\%) extracts of aerial parts C. papaya were analyzed for their anticancer effect against three types of cancer cells such as UACC62 (melanoma) TK10 (renal) and MCF7 (breast) cancer cells. It was concluded that the petroleum extract of papaya aerial parts had a significant effect on MCF7 (breast) cancer cells. One research report concluded that black seed from yellow ripe papaya has a direct effect to reduce the growth of prostate cancer cells. Methanolic extract of black seed (ripe papaya) and white seed (unripe papaya) was tested against the prostate cancer cell line. It has been reported that the black seed extract is effective against prostate cancer cells whereas the white seed shows a stimulating effect on pre-existing prostate cancer cells. Another research study reported that papaya leaf juice has also an anti-proliferative effect on prostate cancer cells [60].

\subsection{Anti-malarial activity}

There were several reports available that support the anti-malarial activity of C. papaya. Papaya along with other plants used by peoples in the treatment of malaria and related symptoms. Another study also revealed about antimalarial effect of methanolic extract of $C$. papaya in mice on Plasmodium bergheiNK65 strain. Also, leaf extract was tested against Plasmodium falciparum 3D7 and Dd2 strains. Carpaine was the most active alkaloid extract in dichloromethane leaf extract and displayed good activity against both strain of Plasmodium falciparumIC50 of $2.01 \pm 0.18 \mu \mathrm{g} / \mathrm{mL}(4.21 \mu \mathrm{M})$ and $2.19 \pm 0.60 \mu \mathrm{g} / \mathrm{mL}(4.57 \mu \mathrm{M})$. This alkaloid is highly selective against the parasite and non-toxic to healthy uninfected R.B.C.

Further, methanol, chloroform, petroleum ether extract of fruit rind, and roots of papaya were tested against Plasmodium berghei in mice for their antiplasmodial activity. The result showed that petroleum ether and chloroform extract of $C$. papaya fruit rind has considerable antiplasmodial activity in a dose-dependent manner but petroleum ether extract had the highest antimalarial activity [60].

\subsection{Anti-dengue activity}

Larvicidal efficiency of chloroform, methanol and aqueous extracts of $C$. papaya latex against larvae of $C$. quinquefasciatus and $A$. aegypti which were effective in a dose-dependent manner. Order of toxicity effect is as chloroform extract $>$ methanol extract $>$ aqueous extract. One report on the clinical trial of $C$. papaya suggested that improve in platelet count of dengue patients and faster improvement. $C$. papaya leaf juice prepared by the traditional method; and two tablespoons of juice were given to 5 dengue patients three times/day after 6 h. It was found that leaf juice causes a significant intensification in the platelet counts within $24 \mathrm{~h}$ of treatment (An increase in platelet count was observed when a patient was given C. papaya leaf extract tablet three times daily for five days and it was suggested that this effect may be due to the expression of the gene responsible for platelet construction named as plateletactivating factor receptor gene. Another investigation has also shown that the leaves of $C$. papaya have a promising effect on to increase in the platelet counts of a dengue patient [60].

\subsection{Anti-inflammatory and immunomodulatory responses}

Papaya contains an extensive range of secondary metabolites such as alkaloids, tannins, flavonoids, saponins, which have been shown to a marked effect to reduce chronic inflammatory reaction. Proteolytic enzymes that are present in papaya such as papain and chymopapain also showed an anti-inflammatory effect as well as an effect on immunomodulation. Papain in combination with other proteolytic enzyme such as trypsin and chymotrypsin reduce TGF- $\beta 1$ level in osteo-myelo-fibrosis, rheumatoid arthritis and herpes zoster. Alkaloids of papaya such as choline and nicotine showed anti-inflammatory potential. In vivo research was performed to investigates the immunomodulatory activities of fruit.

It is also reported that transgenic and native papaya fruit (both ripe and unripe) have significant immunomodulatory properties. These immunomodulatory effects were observed in the ovalbumin sensitized mouse model. A remarkable decrease in OVA-specific IgE titre was noticed with native green papaya fruit, whereas an increase in OVA-specific IgG2a titre was observed with green and ripened papaya fruit. The ripened transgenic papaya fruit has a significant increase in IgM level which leads to enhanced humoral immunity. Another study also showed that the seed extract of this plant has both anti-inflammatory activity and immunomodulatory effects. For instance, the bioactive reactions and immunomodulatory effect of crude seeds extract of this plant were investigated in vitro using comp Papaya contains an extensive range of secondary metabolites such as alkaloids, tannins, flavonoids, saponins, which have been shown to a marked effect to reduce chronic inflammatory reaction. Proteolytic enzymes that are present in papaya such as papain and chymopapain also showed an anti-inflammatory effect as well as an effect on immunomodulation [61]. 


\section{Conclusion}

From the research study, it is concluded that phytoconstituents obtained from c. papaya are best alternative to combat the diseases. This is one of most versatile plants which has been used for medicinal as well as in household purposes. All parts of plants had been used in the prevention and treatment of various diseases. Different extracts have been found possessing various pharmacological activities. Further comprehensive work is required, because the literature shows limited research in several areas to understand and disclose the mode of its pharmacological activities.

\section{Compliance with ethical standards}

\section{Acknowledgments}

Authors are thankful to Shri. YogendrajiGode, President, IBSS's Dr. Rajendra Gode Institute of Pharmacy, Amravati and Dr. Rajendra Gode College of Pharmacy, Amravati for providing necessary facility to undertake this work.

\section{Disclosure of conflict of interest}

The author declares no conflict of interest

\section{References}

[1] Ayurvedic Formulary of India, Ministry of Health and Family Planning, Government of India. The Controller of Publications: New Delhi; 2001.

[2] Manwar JV, Mahadik KR, Sathiyanarayanan L, Paradkar AR, Patil SV. Comparative antioxidant potential of Withania somnifera based herbal formulation prepared by traditional and non-traditional fermentation processes. Integr Med Res. 2013; 2:56-61. http://dx.doi.org/10.1016/j.imr.2013.04.002

[3] The Wealth of India. A dictionary of Indian raw materials and industrial products- raw materials publications and information, Directorate Council of Scientific and Industrial Research, New Delhi, India; 1962; pp: 207-215.

[4] Manmode R, Manwar J, Vohra M, Padgilwar S, Bhajipale N. Effect of preparation method on antioxidant activity of ayurvedic formulation kumaryasava. J Homeop Ayurv Med. 2012; 1:114. doi:10.4172/2167-1206.1000114.

[5] Padgilwar S, Manwar J, Vohra M, Banginwar Y. Traditional Uses, Phytochemistry and Pharmacology of Oroxylum Indicum: A Review. International Journal of Pharmaceutical and Phytopharmacological Research. 2014; 3 (6):483-486.

[6] Manwar JV, Mahadik KR, Paradkar AR, Takle SP, Sathiyanarayanan L, Patil SV. Determination of withanolides from the roots and herbal formulation of Withania somnifera by HPLC using DAD and ELSD detector. Der Pharmacia Sinica. 2012; 3:41-46.

[7] Manwar J, Mahadik K, Paradkar A, Patil S, Sathiyanarayanan L, Manmode R. Gas chromatography method for the determination of non-ethanol volatile compounds in herbal formulation. International Journal of Analytical and Bioanalytical Chemistry. 2013; 3(1):12-17.

[8] Badukale NA, et al. Phytochemistry, pharmacology and botanical aspects of Madhuca indica: A review. Journal of Pharmacognosy and Phytochemistry. 2021; 10(2): 1280-1286.

[9] Manwar J, Mahadik K, Paradkar A, Sathiyanarayanan L, Vohra M, Patil S. Isolation, biochemical and genetic characterizations of alcohol-producing yeasts from the flowers of Woodfordia fruticosa. J Young Pharm. 2013;5(4):191-194.

[10] Sahare AY, Padgilwar SS, Chaudhari Y, Manwar JV. Hypericum perforatum: A Medicinal plant. Plant Archives. 2007; 7(2):463-468.

[11] Khadatkar S, Manwar J, Bhajipale N. In-vitro anthelmintic activity of root of Clitoria ternatea Linn. Pharmacognosy magazine.2008; 4 (13):148-150.

[12] Khadatkar SN, Manwar JV, Sahare AY. Preparations and evaluation of microcapsules of capsaicin. International Journal of Chemical Sciences. 2007; 5(5):2333-2341.

[13] Sahare AY, et al. Antimicrobial activity of Pseudarthria viscida roots. Asian Journal of Microbiology Biotechnology \& Environmental Sciences. 2008; 10(1):135-136. 
[14] Nugroho A, Heryani H, SueChoi J, Park H. Identification and quantification of flavonoids in Carica papaya leaf and peroxynitrite scavenging activity. Asian Pac J Trop Biomed. 2017; 7(3):208-213.

[15] Mohammad AH, Sabtu Hitam. Pharmacological and toxicological activities of the extracts of papaya leaves used traditionally for the treatment of diarrhoea. Journal of King Saud University- Science.2020; 32:962-969.

[16] Oloyede O. Chemical Profile of Unripe Pulp of Carica papaya. Pakistan Journal of Nutrition.2005; 4(6):379-381.

[17] Yogiraj VA, Goyal PK, Carica papaya Linn: An Overview. International journal of Herbal Medicine 2014; 2(5):0108.

[18] Sharma A, Joshi A, Sharma P, Bachheti R, Husen Azamal. Phytochemistry, pharmacological activities, nanoparticle fabrication, commercial products and waste utilization of Carica papaya L.: A comprehensive review. Current Research in Biotechnology. 2020; 2:145-160

[19] Peter J, Kumar Y, Pandey P, Masih H, Antibacterial Activity of Seed and Leaf Extract of Carica Papaya var. Pusa dwarf Linn. Journal of Pharmacy and Biological Sciences. 2014;9(2):29-37.

[20] Jaime A, et al. Papaya (Carica papaya L.) Biology and Biotechnology. Tree and Forestry Science and Biotechnology. 2007; 1(1):47-73.

[21] Gunde M, Amnerkar N, Nutritional, medicinal and pharmacological properties of papaya (Carica papaya linn.): A review. Journal of Innovation in pharmaceuticals and biological science. 2016; 3(1):162-169.

[22] Panchale WA, et al. Chromatographic analysis of famotidine, paracetamol and ibuprofen from tablet formulation. Research Journal of Pharmacy and Technology, 2019; 12:231-263.

[23] Panchale WA, et al. Concurrent analysis of ambroxol $\mathrm{HCl}$ and salbutamol sulphate from tablet formulation by RP-HPLC. GSC Biological and Pharmaceutical Sciences. 2020; 13(03): 197-202.

[24] Sabhadinde AF, et al. Novel RP-HPLC method for simultaneous analysis of chlorthalidone and telmisartan from combined dosage form. International Journal of Pharmacy and Pharmaceutical Research. 2020; 20(1):491-502.

[25] Panchale WA, et al. RP-HPLC method for simultaneous determination of escitalopram oxalate and flupentixol $\mathrm{HCl}$ in tablet dosage form. GSC Biological and Pharmaceutical Sciences. 2021; 14(01):169174ttps://doi.org/10.30574/gscbps.2021.14.1.0004

[26] Nimbokar SW, et al. Development and validation of RP-HPLC method for determination of zonisamide from tablet formulation. World Journal of Pharmaceutical and Medical Research. 2021;7(2):196-200

[27] Manwar JV, et al. Development of newer RP-HPLC method for simultaneous estimation of cefixime and linezolide in bulk drugs and combined dosage form. International Journal of Pharmacy and Life Sciences. 2021; 12(1):26-31

[28] Panchale WA, Gulhane CA, Manwar JV, Bakal RL. Simultaneous estimation of salbutamol sulphate and ambroxol $\mathrm{HCl}$ from their combined dosage form by UV-Vis spectroscopy using simultaneous equation method. GSC Biological and Pharmaceutical Sciences. 2020;13(03):127-134.

[29] Pophalkar PB, et al. Development and evaluation of ondansetron medicated jelly. World Journal of Pharmaceutical Research. 2018; 7(19):1252-1263.

[30] Panchale WA, Bakal RL. First-order derivative spectrophotometric estimation of gemifloxacin mesylate and ambroxol HCl in tablet dosage form. GSC Biological and Pharmaceutical Sciences.2021; 14 (2):029-036.

[31] Bakal RL, et al. Spectrophotometric estimation of amitriptyline HCL and chlordiazepoxide in tablet dosage form. International Journal of Chemical Sciences. 2007; 5(1): 360-364.

[32] Manwar JV, et al. Application of simultaneous equation method for the determination of azithromycin and cefixime trihydrate in tablet formulation, Research Journal of Pharmacy and Technology. 2017; 10(1):108-112.

[33] Manwar JV, et al. Response surface based optimization of system variables for liquid chromatographic analysis of candesartan cilexetil. Journal of Taibah University for Science. 2017; 11:159-172.

[34] Gulhane CA, et al. Liquid chromatographic method for simultaneous estimation of thiocolchicoside and etoricoxib from tablet formulation. Asian Journal of Pharmaceutical Analysis. 2021;11(3).

[35] Manwar J, Mahadik K, Paradkar A, Patil S, Sathiyanarayanan L, Manmode R.Gas chromatography method for the determination of non-ethanol volatile compounds in herbal formulation. International Journal of Analytical and Bioanalytical Chemistry. 2013; 3(1):12-17. 
[36] Wadekar AB, et al. Formulation and evaluation of extended release tablet of metoprolol succinate. World Journal of Pharmacy and Pharmaceutical Sciences.2016; 5(6):1302-1316.

[37] Wadekar AB, et al. An overeview on exosome: Natural drug delivery vehicle. World Journal Of Pharmacy and Pharmaceutical Sciences. 2013; 2(1):75-88.

[38] Kadam CY, et al. Design and in vitro characterization of phase transition system using rivastigmine tartrate for nasal drug delivery system. World Journal of Pharmaceutical Research. 2018; 8(1):815-829.

[39] Suroshe RS, et al. Development and Characterization of Osmotic Drug Delivery System of Model Drug. World Journal of Pharmaceutical Research. 2018; 7(18):1158-1171.

[40] Patil SS, Kumbhar DD, Manwar JV, Jadhao RG, Bakal RL, Wakode S. Ultrasound-Assisted Facile Synthesis of Nanostructured Hybrid Vesicle for the Nasal Delivery of Indomethacin: Response Surface Optimization, Microstructure, and Stability. AAPS PharmSciTech. 2019 Jan 29;20(3):97. doi: 10.1208/s12249-018-1247-1.

[41] Nimbalwar MG, Upadhye K, Dixit G. Fabrication and evaluation of ritonavir proniosomal transdermal gel as a vesicular drug delivery system. Pharmacophore. 2016; 7(2):82-95.

[42] Santana LF, et al. Nutraceutical Potential of Carica papaya in Metabolic Syndrome. Nutrients. 2019 Jul 16;11(7):1608. doi: 10.3390/nu11071608.

[43] Saikia I, Hazarika M, Tamuly C. Synthesis, characterization of bio-derived ZnO nanoparticles and its catalytic activity. Materials Letters.2015; 167(161):29-32.

[44] Sangsoy K, et al. Papaya carotenoids increased in Oxisols soils. Journal of Agriculture and Natural Resources. 2017; 4(51):253-261

[45] Rahayu R, Darmis A, Jannatan R. Potency of papaya Leaf (Carica papaya L.) as toxicant and repellent against german cockroach (Blattellagermanica L.). Pakistan Journal of Biological Sciences. 2020; 23(2):126-131.

[46] Muthukumar T, et al. Green synthesis of gold nanoparticles and their enhanced synergistic antitumor activity using HepG2 and MCF7 cells and its antibacterial effects. Process Biochemistry 2016; 3(51):384-391.

[47] Prabhu Akshata, et al. Antidiarrheal activity and phytochemical analysis of Carica papaya fruit extract. Journal of Pharmaceutical Sciences and Research 2017; 9(7):1151-1155.

[48] Nayak S, Pinto Pereira, Maharaj D. Wound healing activity of Carica papaya L. in experimentally induced diabetic rats. Indian Journal of Experimental Biology. 2007; 45(8):739-43.

[49] Sianipar, M.P, Suwarso, E, Rosidah, R, 2018. Antioxidant and anticancer activities of hexane fraction from Carica papaya l. male flower. Asian Journal of Pharmaeutical and Clinical Research 2018; 11(3):81-83.

[50] Tarkang PA, et al. Antioxidant potential of a polyherbal antimalarial as an indicator of its therapeutic value. Advances in Pharmacological and Pharmaceutical Sciences. 2013; 1(1):1-9.

[51] Singh P, Rawat P. Evolving herbal formulations in management of dengue fever. Journal of Ayurveda and Integrative Medicine. 2017; 8(3):207-210.

[52] Mabley J, Gordon S, Pacher P. Nicotine exerts an anti-inflammatory effect in a murine model of acute lung injury. Inflamation. 2011; 34(4):231-237.

[53] Sani MA, Bakar J, Rahman RA, Abas F. Effects of coated capillary column, derivatization, and temperature programming on the identification of Carica papaya seed extract composition using GC/MS analysis. Journal of Analysis and Testing 2020; 4(1):23-34.

[54] Sharma SC, ZnO nano-flowers from Carica papaya milk: degradation of alizarin red-S dye and antibacterial activity against Pseudomonas aeruginosa and Staphylococcus aureus. Optik. 2016; 127(16):6498-6512.

[55] Singh 0, Ali M. Phytochemical and antifungal profiles of the seeds of Carica papaya L. Indian J. Pharm. Sci. 2011; 73:447-451.

[56] Singh PG, In vitro antioxidant, anti-inflammatory and anti-microbial activity of Carica papaya seeds. Glob. J. Med. Res. 2020; 20:19-38.

[57] Singh, S.P, Kumar, S, Mathan, S.V, Tomar, M.S, Singh, R.K, Verma, P.K, Kumar, A,Kumar, S, Singh, R.P, Acharya, A, 2020. Therapeutic application of Carica papaya leaf extract in the management of human diseases. DARU J. Pharm. Sci. 
[58] Singh SP, Kumar S, Mathan SV, Tomar MS, Singh RK, Verma PK, Kumar A, Kumar S, Singh RP, Acharya A. Therapeutic application of Carica papaya leaf extract in the management of human diseases. Daru. 2020 Dec;28(2):735-744. doi: 10.1007/s40199-020-00348-7.

[59] Pandey S, et al. Bio-guided fractionation of papaya leaf juice for delineating the componentsresponsible for the selective anti-proliferative effects on prostate cancer cells. Front. Pharmacol. 2018; 9:1-10.

[60] Pandey S, et al. Anti-inflammatory and immunomodulatory properties of Carica papaya. J. Immunotoxicol. 2016; 13:590-602.

[61] Renganathan S, et al. Silver nanoparticle synthesis from Carica papaya and virtual screening for anti-dengue activity using molecular docking. Mater. Res. Express. 2019; 6:35028. 